\title{
Grudging Respect? \\ Kaigun Through the Lens of the US Navy at the Time of the Sino-Japanese War ${ }^{1}$
}

\section{John T. Kuehn}

\begin{abstract}
En 1890, les États-Unis et le Japon avaient commencé à se manifester comme puissances navales. Il était donc logique que les officiers de la marine américaine aient des opinions sur la montée de leur "voisin » du Pacifique. Le récit que les historiens ont élaboré sur la façon dont ces deux pays sont devenus concurrents dans le Pacifique repose sur le fait que nous savons ce qui s'est passé. Pourtant, dans les années 1890, le Japon et les États-Unis se regardaient l'un l'autre de manière beaucoup plus favorable que nous l'imaginons. L'examen des perceptions des officiers de la marine américaine illustre un point de vue davantage complexe, nuancé et positif. Les tendances et les connaissances observées sont toujours valables aujourd'hui : les défis actuels dans le Pacifique qui facilitent la compréhension des relations avec le Japon sont particulièrement semblables à ceux des années 1890.
\end{abstract}

Perceptions matter. Over 120 years ago two naval powers began emerging on the stage of naval history, Japan and the United States. It was only natural that the US Navy officers had opinions about the rise of their Pacific "neighbor." We after-thefact-folks tend to look back at the emergence of these two maritime powers and then construct a narrative about how two nations became rivals in the Pacific because we know happened afterward - the Japanese-American antagonism, especially in the naval sphere, that led to first hostility and then war in 1941. This narrative is flawed.

\footnotetext{
${ }^{1}$ This article is based on research presented as a paper at the Society of Military History Conference in April 2016 in Ottawa, Canada and supported by the US Army Command and General Staff College in terms of time and money for travel. The views expressed here are those of the author and do not reflect the official policy or position of the Department of the Army, Department of Defense, or the US Government.
}

The Northern Mariner/Le marin du nord, XXVI, No. 3 (July 2016), 259-274. 
As N.A.M. Rodger wrote, "Our problem is not that we know too little history to understand the present but that we know too much, and most of it is wrong." 2 The truth of the matter, at least in the 1890s, was that Japan and the US regarded each other far more favourably than some historians have led us to believe. Close study of the era and of the perceptions of US naval officers reveals a more complex, nuanced, and positive viewpoint. One can find patterns and insight for today and the challenges that exist in the Pacific and that inform the understanding of a relationship with Japan today that is surprisingly more similar to 120 years ago than one might imagine.

$$
* * *
$$

Kaigun means "navy" in Japanese; navy as in a fleet of warships supported by the infrastructure and policy of a nation-state. The Imperial Japanese Navy (IJN) was one of the most astonishing accomplishments of the Meiji era of Japanese history. It emerged in the late nineteenth century as one of the fastest rising fleets in history, developing from an odd collection of warlord (daimyo) vessels to a world-class navy in little more than a generation. This rapid rise, and then its victorious record in two major regional wars in a decade with other powers, China in 1894-95 and Russia in 1904-1905, served notice to the European powers and the United States that a new force had to be reckoned with in the Far East. This was a force that none of them could have imagined even existing a mere fifty years earlier. ${ }^{3}$ To what extent did this meteoric rise capture the attention, admiration, indeed even the imaginations of the professional officer corps of the other great powers, especially that other "new kid on the block" as a great naval power, the United States Navy?

In 1894 the Sino-Japanese War pitted the navies of China and Japan, two Asian powers that had recently modernized their fleets, against each other. Japan's swift and decisive victory over China changed the balance of power in northeast Asia and resulted in a confrontation between Japan and Russia over their extraterritorial rights in Manchuria, the Liaodong Peninsula, and Korea. ${ }^{4}$ Japan's subsequent signing of the Anglo-Japanese Naval Treaty in 1902 brought Japan further into the foreground of American strategic thinking. Not long after the the destruction of a Russian fleet in the Tsushima Strait added further luster to the

\footnotetext{
${ }^{2}$ N.A.M. Rodger, “The Perils of History," Inaugural Hattendorf Prize Lecture, Naval War College Review, 66:1 (Winter 2013), 8.

${ }^{3}$ For a complete early history of Kaigun in English see David C. Evans and Mark R. Peattie, Kaigun: Strategy, Tactics, and Technology in the Imperial Japanese navy, 1887 - 1941 (Annapolis, MD: Naval Institute Press, 1997), chapters 1-4. For a more institutionally and culturally focused history see Sadao Asada, From Mahan to Pearl Harbor: The Imperial Japanese Navy and the United States (Annapolis, MD: Naval Institute Press, 2006).

${ }^{4}$ Extraterritorial as used here means a loss of sovereignty by Qing state. The foreign powers with "concessions" in China governed almost absolutely inside the territories under their control, to include their own courts and laws, immune from Chinese law and power. See Jonathan D. Spence, The Search for Modern China (New York: WW Norton \& Coo., 1990),161-162
} 
reputation of the $\mathrm{IJN} .^{5}$

In 1906 famed sea power theorist and foreign policy pundit A.T. Mahan abandoned his self-imposed "blockade" of the United States Naval Institute's Proceedings and penned an account of the defeat of the Russian fleet by the IJN at "The Battle of the Japan Sea" (Battle of Tsushima Strait) that reflected what might be characterized as a laudatory attitude. ${ }^{6}$ With Japan's victory over Russia, and a peace negotiated due to the good offices of navalist President Theodore Roosevelt, American naval officers considered the possibility of Japan as a potential threat, resulting in the initiation of the war planning by the General Board of the navy the navy's premier planning organization of the period. This plan eventually became known as War Plan Orange. ${ }^{7}$

The advent of the Japanese, never mind their naval power, in the psyche of American naval officers occurred before that of most other Americans. This was because of the instrumental role the United States Navy played in opening Tokugawa Japan to the world in the mid-nineteenth century. Japan's production of cash crops such as silk and manufactured items like pottery and bone china attracted the attention of Western trading powers seeking these commodities as well as to open new Japanese markets for their own goods. ${ }^{8}$ In 1853, a new US administration decided to coerce a trade relationship with Japan and dispatched Commodore Matthew C. Perry of the United States Navy on his famous (or infamous) mission. Perry arrived that July with four ships and a draft treaty of friendship between the United States and Japan. The Tokugawa Shogun kept Perry waiting while his advisors consulted with the major samurai lords about what to do. Perry departed Japan believing his request would be delivered to the emperor and returned the following year with seven ships and a draft treaty. On 31 March 1854 Perry and the Japanese envoys signed the Treaty of Kanagawa, establishing a "permanent friendship" between the two nations, guaranteeing safety for shipwrecked Americans, ensuring coal for American ships, and providing the promise of future trade. This momentous event shattered Japan's isolation from the West - primarily due to the influence of the US Navy. ${ }^{9}$

\footnotetext{
5 John T. Kuehn, A Military History of Japan: From the Ages of the Samurai to the $21^{\text {st }}$ Century (Santa Barbara, CA: Praeger, 2014), 147-167.

${ }^{6}$ Mahan's boycott of Proceedings is not well-known or written about much in the biographies and books about him. The man and the institute ran afoul of each other for a complex series of reasons that is best illustrated in Mark W. Wever, "The Influence of Captain Alfred Thayer Mahan Upon the United States Navy Through the United States Naval Institute's Proceedings," unpublished master's thesis (Fort Leavenworth, KS: US Army Command and General Staff College, 2013), passim. See also, A.T. Mahan, "Reflections, Historic and Other, Suggested by the Battle of the Japan Sea," United States Naval Institute, Proceedings 32:2 (1906), 447-471.

7 See Edward S. Miller, War Plan Orange (Annapolis, MD: Naval Institute Press, 1991).

${ }^{8}$ Michael Laver, "A Whole New World (Order): Early Modern Japanese Foreign Relations, 1550-1850," in Karl Friday, ed., Japan Emerging: Premodern History to 1850 (Boulder, CO: Westview Press, 2012), 340-341.

${ }^{9}$ United States Naval Heritage and History Command government website. http:/www.history.navy.mil/research/library/exhibits/commodore-matthew-c-perry-and-theopening-of-japan.html (accessed 08 March 2016).
} 
A fascinating parallel between the post-Civil War USN and the IJN. The US Navy rapidly downsized after that conflict and reverted to a second rate, or even third rate, naval power. It only began to modernize itself in the 1880 s, almost at the same time the Kaigun was growing and modernizing. The two navies were similar in size during this period and both had relatively enlightened officer corps; both, focused on developing a modern naval professionalism equal to the progressive times.

In the decade prior to the Sino-Japanese War, Kaigun saw improvements in equipment first. The reforms to its navy grew out of Japan's security concerns. Naval policy and planning was contained within the Navy Ministry, and a naval general staff was not established until 1889, although it remained under the control of the Navy Ministry. For the IJN's leaders, the immediate threat to Japan was the German-built Chinese fleet, which had also recently modernized. ${ }^{10}$ China had hired foreign officers to help with this effort, including Philo McGiffin a graduate of the US Naval Academy. ${ }^{11}$ Initiating a propaganda campaign for "maritime Japan," the naval leadership took advantage of public enthusiasm to improve the fleet. To this end, Japan acquired two lightly armoured big-gun cruisers, Matsushima and Itsukushima, in 1891. The navy was controlled by a faction composed of samuraiofficers from Satsuma, the key leader being Navy Minister Saigo Tsugumichi, the loyal younger brother of the rebel Saigo Takamori. Saigo Tsugumichi was an army general, not a sailor, although he was granted the title of full admiral in 1894 in honour of his efforts in building up the IJN. ${ }^{12}$

Within the IJN the key leader, though, was Yamamoto Gombei (no relation to the admiral of Second World War fame), who looked to Great Britain to model the nation's navy. ${ }^{13}$ Yamamoto secured a position as the personnel manager of the IJN in the early 1890 s and swept away much of the "deadwood" in the nascent officer corps. His partisanship for a large navy eventually put him at odds with the Imperial Japanese Army (IJA) and marked the beginning of mutual antipathy between the two services that lasted until both were destroyed in the Second World War. By the beginning of the Sino-Japanese War, Saigo, Yamamoto, and their confederates had built a formidable "fleet-in-being." This "combined fleet" numbered twenty-four major warships under the command of Admiral Ito Yuko, formerly the head of Japan's Naval Staff College. Ito's second in command, Rear Admiral Tsuboi Kozo, had trained with the USN as a younger officer. This fleet's great advantage over the Chinese ships would be its high speed, the better training of its crews, and the professionalism and leadership of its officers. ${ }^{14}$

\footnotetext{
${ }^{10}$ Evans and Peattie, Kaigun, 7-8.

11 Richard Harding Davis, Real Soldiers of Fortune (New York: Charles Scribner's Sons, 1911), 127-131.

12 Evans and Peattie, 15-20, 532.

13 See for example Lisle Rose, Power at Sea:The Age of Navalism, 1890-1918, Volume I

(Columbia, MO: University of Missouri Press, 2007), 97-98.

${ }_{14}$ Evans and Peattie, 20-25, 524-525. The term fleet-in-being comes from Sir Julian Corbett,

Some Principles of Maritime Strategy (Annapolis, MD: Naval Institute Press, 1988, reprint), 234.
} 
Turning to how US officers viewed the IJN on the eve of the Sino-Japanese War, a few notes on sources are in order, especially the United States Naval Institute Proceedings. At the end of every issue of the Proceedings (which was published quarterly), there was a section entitled "Professional Notes" (hereafter notes). These notes were written by officers who were members of the Naval Institute, aided in some cases by an academic-scholar who also helped with translations of foreign language naval articles and press releases of interest. These "editors" were often fairly junior officers (lieutenants and below). Exact authorship of various notes is not specific, other than sometimes attributed translations. Thus it must be assumed that any view was the collective view of these editor-officers. These notes provide a lucrative hunting ground for information and American attitudes on the Japanese, given that the Naval Institute followed contemporary developments closely. Normally the papers and articles published in the Proceedings had been presented at institute meetings. The journal included responses by other members, either given at the meetings or in writing subsequently. These responses were often published following the papers. Both the articles and comments reflect the institutional attitudes and concerns of navy officers.

Prior to the Sino-Japanese War the interest in the Japanese as reflected in the Proceedings was perfunctory - essentially one minor naval power (the US) and its interest or curiosity in another, Japan, of about equal size with whom it shared an oceanic frontier. In the 1893 volume for example, the notes when listing the great naval powers of the world, mention neither Japan nor the US navies. ${ }^{15}$ However, Japan's acquisition of the newly constructed protected cruiser Yoshino in 1892 from Great Britain did get almost a page of commentary in the notes. The commentary focused on the cruiser's characteristics, emphasizing that an engineering magazine claimed her speed made her "the fastest sea-going vessel in the world." The navy officer commentator then reserved judgment until he could see for himself how that speed was measured. He did, however, praise the ship for a "very high degree of handiness and manoeuvring power essential to a cruiser of her class." Most of the short section, thus, focused on the attributes of the hardware and maintained a slightly sceptical professional tone. However, at the end the author congratulated the "Japanese Government" for making the acquisition of "one of the finest, swiftest, and most powerful warships of her class afloat." "This final comment may be more aimed at the US government than in praise of the Japanese leadership, but it does indicate objectivity of a sort without hint of the latent racism that one can find in some later comments about the Japanese and Chinese after the news of Japanese victories in the Sino-Japanese War began to take up more space in Proceedings.

That space was not long in coming as the issues of 1894, the year the war Sino-Japanese War broke out, were published and then consolidated. In review, Japan's navy surprised everyone (as did its army) with a series of initial victories at the outset of the war. At first it seemed the IJN had failed to neutralize the Chinese

\footnotetext{
15 "Professional Notes" Proceedings, 19:4 (1893), passim.

16 Proceedings, 20:2 (1894), 456-457; Evans and Peattie, 17.
} 
fleet under Admiral Ding (Ting). However on 17 September 1894 Japanese Admiral Ito Yuko attacked and defeated Ding's fleet, which was covering a convoy of troopships disembarking nearby at the mouth of the Yalu River. Five Chinese ships were sunk and four (including the battleships) heavily damaged as compared to four seriously damaged Japanese warships. The Chinese suffered over 1,300 killed and wounded as compared to the Japan's less than $300 .{ }^{17}$ Shortly thereafter Admiral Ito and the combined fleet bottled up the Chinese fleet in its main northern base at Weihaiwei. The Kaigun proved that it could act effectively both at sea and in combined (or joint) operations with the army along the sea-land interface. In combined attacks after an amphibious landing by the Japanese Army, Weihaiwei was reduced in February 1895 and a treaty ending the war in Japan's favour was signed that April. That treaty was later overturned to a great degree by the major European powers. ${ }^{18}$

One of the first commentaries on the Japanese naval prowess to appear came from none other than A.T. Mahan, but not in Proceedings. Shortly after the Battle of the Yalu, while in command of the USS Chicago conducting a port visit to Southampton, England, a reporter from the Times of London cornered Mahan and asked for his opinion on the battle. ${ }^{19}$ Mahan freely admitted his incomplete knowledge of the battle and used the circumstances then known about the battle to make some general comments "upon the lessons to be learned from the from the encounter." Subsequently, the rest of the interview focused not on Japanese excellence or Chinese failure so much as the larger issues of naval strategy involved. However, Mahan emphasized that he thought the battle "undoubtedly an important one for modern warships, but..." there was nothing he had yet learned (and he admitted he needed more information) to indicate "a reconstruction and remodelling of European fleets. ${ }^{, 20}$ This was as close as Mahan got to any sort of critical response - but he did not dismiss the engagement as of no value because of the different race and nationality of the protagonists.

Mahan had previously regarded Japan with a special sort of reverence. For example, upon visiting Japan during the 1860s, at the time of her Meiji upheavals, he wrote: "The country is more beautiful than anything in our own land. Just between Kobe and Osaka is one of the loveliest, if not the loveliest rural view I have ever seen." Of course this is more a comment on landscape than on the potentialities of the national character. Nonetheless, Mahan regarded himself as something of an expert on Japan because of his year-long visit there in 1867-68, what we might term a foreign area officer today - albeit self-appointed. The eminent Japanese historian Sadao Asada pronounces a two-dimensional characterization of Mahan as, on the

\footnotetext{
${ }^{17}$ Kuehn, 149-152.

${ }^{18}$ Ibid., 152.

19 A. T. Mahan, 30 September 1894, in Letters and Papers of Alfred Thayer Mahan, vol. 2 (Annapolis, MD: Naval Institute Press, 1975), 336-337.

${ }^{20}$ A. T. Mahan, "The Battle of the Yalu: An Interview with the Times," London, September 25, 1894, in Letters and Papers of Alfred Thayer Mahan, vol. 3 (Annapolis, MD: Naval Institute Press, 1975), 583-585.
} 
one hand, admiring the Japanese people and culture, while, on the other, regarding immigration and the policies of its government as a threat. However Mahan clearly had a firm basis for a professional opinion on the officers of Kaigun, having instructed many Japanese midshipmen in gunnery as exchange students at the Naval Academy from 1877 to 1880 . One later became a full admiral after the RussoJapanese War. ${ }^{21}$

Shortly after Mahan's Times interview more information did come out and the next Proceedings issue devoted substantial portions of its notes to two pieces. The first piece printed in the notes was a letter to the Times of London reprinted in Proceedings by an anonymous "naval officer." This officer was almost certainly the expatriate American Philo N. McGiffin, who had been second officer on board one of the Chinese battleships at the battle. The closing lines support this hypothesis, as the author wrote, "This [Japanese gunnery] superiority, as has always been the case, would have been barren of result had not the Japanese been sufficiently practised in manoeuvring at sea to enable them to avail themselves of its effect." 22 This seems a clear identification that training at one's craft was essential to a margin of victory. McGiffin was a fascinating character. A graduate of the US Naval Academy who had not graduated high enough to be granted a commission in the small US Navy, he had gone to China where he helped teach in its budding training and education structure, including its analog of the US Naval War College. He had served in combat at the Yalu, being grievously wounded while in de facto command of the one of the two Chinese battleships at the engagement. Later, in a longer article for Century magazine McGiffin wrote: "Monday, the memorable 17th of September [1894], was a beautiful day, a light breeze gently ruffling the surface of the water. .... [the] twelve Japanese ships, forming apparently a single line and preserving station and speed throughout most beautifully, could not but excite a feeling of admiration." 23

Certainly these two passages, one possibly from a letter to the Times in 1894 and another in 1895, emphasize an unbiased and respectful attitude toward the Japanese. In the later article he also praised his own Chinese sailors and the Japanese a bit more specifically, crediting the Japanese victory to "better ships, more of them, better and larger supplies of ammunition, better officers, and as good men." ${ }^{24}$ However, as an expatriate and an actual participant in a conflict against the Japanese, one cannot consider McGiffin a fair representation of the attitudes of serving US naval officers.

Immediately following the Times piece in the same issue of Proceedings was "The Naval Battle of Haiyang, A Japanese Account." Haiyang is simply another name given to the battle at the time and this was the name attached to this translation

\footnotetext{
21 See Sadao Asada, From Mahan to Pearl Harbor, 6.

${ }^{22}$ Anon., "The Lessons of the Engagement off the Yalu," notes, in Proceedings, 20:4 (1894), 806. Emphasis added.

${ }^{23}$ Philo N. McGiffin, "The Battle of the Yalu: Personal Recollections by the Commander of the Chinese Ironclad 'Chen Yuen',' Century: A Popular Quarterly Volume, 50:4 (August 1895), 587.

${ }^{24}$ McGiffen, 597-605. Emphasis added.
} 
of the Japanese account. It included maps, tables, and diagrams and offered a straightforward account that tended to emphasize the prudence of Japanese officer leadership. There was no editorial comment on either piece; presumably Proceedings' readership were to come to their own conclusions based on these accounts. ${ }^{25}$ However, the editorial "voice" of Proceedings asserted itself on this issue shortly thereafter, in the final section, "Bibliographic Notes." Under an entry entitled "October 13 About the Battle of Yalu" one reads the following commentary:

In the absence of important factors that constitute the naval battle at Yalu, it would be presumptuous at this time to offer any lesson upon the engagement. But one point upon which most naval officers will agree is that if two European squadrons composed about the same as the Chinese and Japanese had fought for five consecutive hours, very little would have been left of them at the end of the action. This consideration must not be lost sight of in commenting upon the battle of Yalu. One Chinese vessel was rammed by a sister ship. Fire found a ready prey in the wood-work. The Chinese firing was poor. The Japanese fire was superior, but still indifferent considering the enormous consumption of ammunition. Besides, the Japs manoeuvred better and maintained good discipline. ${ }^{26}$

This passage is certainly worthy of note, since it stands in contrast to some of things reflected by the writing of Mahan and especially McGiffin (and possibly a third officer if the Times letter was written by someone else.) Here one detects an ethnocentric, if not racist, attitude. Although use of the term "Jap" only disappeared in American usage in the last quarter the twentieth century, it still emphasizes the point, even though it precedes a sort of back-handed compliment. ${ }^{27}$ The author or authors believed it important to de-emphasize or modulate the lessons offered in the two reproduced accounts and then to emphasize the "lesson" that these were Orientals and certainly Europeans would have done better. No other bibliographic entries had such commentary.

The reviewers and translators for this issue are listed as US Navy lieutenants Hugo Osterhaus, J.H. Glennon, H.G. Dressel, and Albert Gleaves. "Prof." Jules Leroux, a longtime scholar who worked with the institute, is also listed. Osterhaus, Glennon, and Gleaves all went on to become admirals in the twentieth century, while Dressel served with distinction in the Spanish-American war. ${ }^{28}$ Gleaves latter

\footnotetext{
25 Anon., "The Naval Battle of Haiyang," Proceedings, 20:4 (1894), 808-818.

${ }^{26}$ Anon., "Bibliographical Notes," Proceedings, 20:4 (1894), 876. Emphasis added.

27 The author was in the audience at the Naval Postgraduate School when Vice Admiral Hank

Metcalf used the term "Jap" in reference to Japanese economic performance as compared to the United States in 1986.

${ }^{28}$ http://www.history.navy.mil/search.html?q=Hugo+Osterhaus, etc. (accessed 08 March 2016).
} 
organized the letters and papers of Rear Admiral Stephen Luce. ${ }^{29}$ These officers were what are now called "hard chargers" in the Navy, and thus provide a more accurate reflection of institutional attitudes than McGiffin or even Mahan.

The first Proceedings issue of 1895 addressed the capture of the Chinese main base at Weihaiwei on the Shandong Peninsula by the Japanese, although it came as a special insert after the notes. Authorship is even harder to determine. The bulk of the information, however, came second hand from a letter by another US "naval officer" aboard a cruiser at Chefoo, China. This officer may have been none other than a young William S. Sims, who was serving on the protected cruiser Charleston in the Far East at this time in a new billet as "intelligence officer." 30 The letter reports, in rather stark language, the suicide of the bulk of the Chinese leadership, including Admiral Ding, shortly after the Japanese captured Weihaiwei on 18 February 1895. Properly characterized as "hearsay" by the editors, it judged the Chinese defence as "farcical," thus undermining to some degree the significance of the Japanese achievement. The idea that friction alone, never mind an inspired defence, can sometimes cause complex combined and amphibious operations of even the best militaries to go awry seems not to have been considered in this judgment. The piece also included an interesting allusion to an account, given to the author in a letter, by "an officer in Chinese service" which that individual found "amusing." Perhaps, again, this officer was McGiffin. ${ }^{31}$ This account credited the Japanese with a highly successful deception tactic, but its dismissive tone about the Chinese climaxes here: "The cowardice, ignorance and knavery of these Chinese 'warriors' is almost beyond belief. They will run from a dozen men...The only obstacle the Japanese have is the weather." 32 Again, one can infer only the attitude toward the Japanese by way of this derogatory language describing the Chinese. To paraphrase, "anyone could beat the Chinese, even the Japanese." Although not stated explicitly one can imagine the readers considering such a conclusion, especially based on some of the earlier comments discussed above about the Yalu. McGiffin may have suffered from the Stockholm syndrome about Orientals in general, and the Chinese in particular, but his observations, written down not long after the battle occurred, stand in contrast to these arrogant and moderately racist attitudes.

As more details about the full extent of the Japanese achievements and operations came out, the tone changed. By this time Mahan had written a longer analysis of the Battle of the Yalu for Century Magazine (summer 1895). He remained objective and complimentary to the Japanese: "After the first collision between the enemies, the Chinese order was soon lost, whereas the Japanese retained control of their own [ships' formation] throughout. This advantage they

\footnotetext{
${ }^{29}$ Rear Admiral Albert Gleaves, editor, Life and Letters of Rear Admiral Stephen B. Luce, U.S. Navy. (New York: G.P. Putnam's Sons, 1925).

${ }^{30}$ Thomas C. Hone, "A WWI Naval Officer's Story," in War on the Rocks (http://warontherocks.com/) 06 September 2013.

31 Anon., Proceedings, 21:1 (1895), 209-210.

32 Ibid.
} 
seem to have utilized in a manner judicious, spirited, and skillful." 33 Interestingly, Mahan did not dismiss the Chinese as outright buffoons, but used the occasion of this engagement to highlight the advantage of the thicker armour on some of their vessels. He devoted most of his article to making a case for several of his pet arguments about ship design, such as the ongoing debate between gunnery versus modern armour. Interestingly, he claimed the battle, despite the excellent Japanese gunnery, proved that armour still had the advantage, at least in 1895 . He also made a clear and succinct strategic and political point about the Chinese "civil" government having constrained its on scene commander in his freedom of action, closing that "...if the man on the spot cannot be trusted, he should be removed; but no one at a distance from the scene of operations can effectively direct them." ${ }^{34}$ Overall, though, the article contained almost no arrogant or racially biased judgements.

The space in Proceedings in 1895 became more and more taken up with articles and notes on the Japanese campaign. The first of these came out in the third issue of the 1895 Proceedings. An "honourable mention" naval essay contest paper written by Ensign Frank Marble was objective and straightforward. It focused almost entirely on the narrative and the facts. Only near the end did some subjective language creep into the article as Marble summarized the battle. "With regard to the loss of life, there is the same appalling inequality [between the Japanese and the Chinese fleets]." 35 However, Marble quickly moved to review in general his own impressions of the accounts to date and the "lessons learned" from this battle: "Many criticisms of [the battle] have been written, opinion the most various and opposite expressed, and scarcely a theory of naval tactics or construction has not been held to have been either proved or disproved by it. In the humble opinion of the present writer, the moral of the tale is very plain." ${ }^{36}$ As it turned out Marble's moral was not so plain, but it boiled down to superior Japanese gunnery and the destructiveness of fires created at sea on modern warships. In all of this he roundly criticized the Chinese while maintaining an objective tone of respect, and even admiration, toward the Japanese, illustrated by this passage: "It is impossible not to admire the mastery of the art [Ito] displayed, while at the same time one wishes he had had a foeman worthier of his steel." Marble added kudos for Ito's flying squadron commander, Admiral Tsuboi, and the Japanese crews. Despite all the criticism of the Chinese, Marble commented that it was "remarkable" that none of their ships surrendered - something that became much rarer in the twentieth century than previously. ${ }^{37}$

Near the end of the article Marble was at his most analytic and objective. Writing "that training, organization, discipline esprit de corps---these are the

\footnotetext{
${ }^{33}$ A.T. Mahan, "Lessons From the Yalu Fight," in The Century, A Popular Quarterly Volume, 50:4 (August 1995), 631.

34 Ibid., 629-632,.

35 Frank Marble, "The Battle of the Yalu," Proceedings, 21:3 (1895), 479-492. Emphasis added.

36 Marble, 493.

37 Ibid., 493-497. Emphasis added.
} 
begetters of victory," he then followed this conclusion with a rather scathing critique of how each western nation chose to see the battle through its own rose-coloured lens.

It is ludicrous to note how the French rejoice that some of the Japanese ships were designed by them; how the Germans congratulate themselves that the Japanese regimental organization was modeled after theirs; how the English, who seemed at first to be not a little chagrined that their friends the Chinamen were getting so badly beaten, now pat themselves on the back because they had share in building the Japanese fleet...; and how we Americans take unto ourselves credit that some of the Japanese officers were trained at the Naval Academy; how all we foreigners congratulate the Japanese on their progress in European civilization and skill in European warfare. Let us rather acknowledge them masters of the art. $^{38}$

And so a young ensign, a new "modern man" saw more clearly perhaps than his "betters" that the Japanese were a force to be reckoned with in their own right. But his attitude, however indicative of the future it represents, served merely as a sounding board for the "older and wiser" comments of the more senior officers whose views were published immediately after this essay.

First up was one of the original naval reformers, Lieutenant Commander Richard Wainwright, member a of distinguished naval family who later became an admiral and whose family had a Cold War guided missile cruiser named after it. ${ }^{39}$ Wainwright was among the group of post-Civil War officers that included Stephen B. Luce and A.T. Mahan who had advocated expansion of the navy and pushed for the establishment of a Naval War College. However, he was something of social Darwinist, believing struggle among nations endemic and that some national "species" were more advanced than others in this regard. ${ }^{40}$ Commenting on Marble's account, Wainwright revealed a somewhat dismissive attitude vis-à-vis the Japanese: "It is doubtful if this [tactic of doubling]... would have been advisable against a more skillful enemy [than the Chinese]... ."41 This contradicted young Marble's closing argument in his paper, which claimed the Japanese are a "samurai" race "terrible in war" (as in terrible to face) and that close study of history revealed as much. ${ }^{42}$ Wainwright continued for several more pages in a similar vein, the old master schooling the young pup, nit-picking the decisions of Admiral Ito - and to

\footnotetext{
38 Ibid., 498. Emphasis added.

39 http://www.history.navy.mil/research/histories/ship-histories/danfs/w/wainwright-ii.html (accessed 09 March 2016).

${ }^{40}$ Ronald H. Spector, Professors at War: The Naval War College and the Development of the Naval Profession (Newport, RI: Naval War College Press, 1977), 83.

${ }^{41}$ Richard Wainwright, "Discussion” Proceedings, 21:3 (1895), 499.

42 Marble, 498-499.
} 
a much greater degree than the more circumspect Mahan had. Over and over again the naval officers of the period use the language of Nelson, and Wainwright did too. The point was not that Ito beat the Chinese, anyone would have, but that the Japanese should have annihilated the entire Chinese fleet a la Nelson, destroyed their troop convoy, that they should have blockaded more effectively. In short, the Japanese Navy was not the Royal Navy that humbled France and Ito was no Nelson. ${ }^{43}$

Wainwright largely avoided derogatory or explicitly racist language and mostly criticized the errors he found in Marble's account or pontificated on his own views. However, at the end the end of his lengthy comments his noblesse oblige and social Darwinism came into clearer focus. After whining (there is no other word for it) that the Chinese fleet was not officered with "men of like characteristics" as the Japanese he wrote:

The Japanese not only have learned well the lessons of [white] civilization, but also have gone beyond and become masters in the art of handling and fighting ships. Their bravery was never a subject of doubt. In this fight we find skill, nerve and ability, with the faster but weaker ships, pitted against the more powerful instruments in the hands of ignorant, apathetic, and not overbrave workmen [the Chinese]. ${ }^{44}$

This seemed to agree with Marble, complementing the Japanese, but the compliment was back-handed in a subtle and nuanced way. Without civilization, perhaps the Japanese bravery would have availed them little against a similarly brave "civilized" navy, say the US Navy. We must be careful to avoid implying meaning which is not here. In fact, it is rather strange that Wainwright mentioned the foreign naval officers, such as Philo McGiffin, in the Chinese fleet but then said nothing about how they seem to have counted for little against the Japanese. ${ }^{45}$

Wainwright, thus, gave the Japanese their due - somewhat grudgingly and represented a more progressive view of the Japanese Navy that seemed to be emerging after the scope and details of their victories, at the Yalu in particular, became clearer. Interestingly, Proceedings then gave space, right after Wainwright, to a Kaigun officer, a naval constructor (today an engineering duty officer) by the name of Y. Wadagaki, I.J.N. from the Yokusuka Naval Yard. Wadagaki's comments focused (at much shorter length) on technical and tactical issues and were mildly critical Marble. Here we find the professionalism and culture nourished by the Naval Institute perhaps at its best, and it may explain the moderation of Wainwright's comments, although we cannot know if the he knew the institute would publish Wadagaki's comments following his own. ${ }^{46}$

\footnotetext{
${ }^{43}$ Wainwright, 499-505.

${ }^{44}$ Wainwright, 505.

${ }^{45}$ Ibid.

${ }^{46}$ Y. Wadagaki, Proceedings, 21:3 (1895), 506-507.
} 
Comments of another US officer, Lieutenant William P. White, came next. He took the interesting tack of analyzing photographs included with the Japanese account and commenting on battle damage and what that could tell one about the battle as compared with Marble's account. White showed the same objectivity that one finds in Marble's account, but provideed mostly technical discussion. ${ }^{47}$ The editors then published Marble's response to all three of these officers - just as one might find in an H-DIPLO or other roundtable review on today's H-NET and as is common at scholarly conferences. ${ }^{48}$ This portion is almost as interesting and valuable as his original article and he was not afraid to challenge the others where he thought himself in the right or to explain his reasons for his claims along with his evidence. He also cited McGiffin's Century article as his most valuable source and took issue with the comments that Mahan published - especially the claim that the battle was not decisive (although Mahan did not directly claim this). Marble also emphasized that both Chinese battleships were effectively commanded by European officers, McGiffin in one and a German officer, Herr von Hanneken, in the other, for much of the latter part of the battle - which further bolstered his claims of Japanese mastery, not just relative mastery due to an inferior enemy. He clearly aligned with McGiffin (and Mahan for that matter) in his view that the Chinese fleet was undone by its officers and government policy (and corruption) as much as Japan was well served by hers. "Commander McGiffin's high praise of the bravery and discipline of his well-drilled crew and the Chinese sailors...cannot be said of the [Chinese] captains." 49

Marble then closeed with a sophisticated, and rather astonishing, discussion of the civil-military relations of the Japanese Navy and its elected Parliament in peace. One forgets that one is reading the words of a young, presumably untested, ensign from over 120 years ago at this point. However, the point to be made is clear from this closing passage:

Happy it is for Japan that in the winter of 1893 — in time of peace - when the controversy over the naval appropriations resulted only in repeated upheavals and adjournments of Parliament, the wiser, steadfast counsel of the Government prevailed. The...farsighted policy of the [Meiji] Emperor himself settled the dispute... . While we wonder at the authority exercised by a Throne, still hedged around with a majesty half divine whose very reality is strange to our republican eyes, the prophetic words with which the Emperor closed his...rescript deserve to be had in everlasting remembrance: 'A single day's neglect may involve a

\footnotetext{
47 William White, Proceedings, 21:3 (1895), 507 - 509, 519.

${ }^{48} \mathrm{H}$-DIPLO is an online forum for diplomatic historians and their roundtable book reviews follow the same format one finds in this 1895 issue of Proceedings. See for example https://networks.hnet.org/node/28443/discussions/114553/h-diplo-roundtable-vol-xvii-no-15-american-grandstrategy (accessed 10 March 2016).

Marble, 510-513, 517.
} 
century of regret.' 50

There are two key points here. First, Marble was arguing that the United States could learn from the Japanese government, and by government he meant its executive branch, although the legislative was certainly discussed as well. The second point follows from the first. He (and probably the editors) wanted to emphasize for the institute's readers the advantages of being properly prepared in peace for war. The war with Spain would prove this point in both positive and negative ways a mere three years later. Marble went on to serve as a flag aide to Admiral Watson in the USS Baltimore in the Far East after that war in 1899 and then, interestingly, we find him as the officer-in-charge of the navy coal depot in Yokohama, Japan in $1906 !^{51}$

Marble's views, then, might be paraphrased as, "The United States Navy, its government, and its people could learn a thing or two from how Japan performed in this war-at all levels." Learning from its successes and best practices, as well as learning from its shortcomings and highlights at the tactical and operational levels of war. That his views might have represented the trajectory of the mainstream of naval officers' thinking was reflected in the very next issue of Proceedings, the last of 1895. In it, Captain Richard Wallach, United States Marine Corps, serving on the faculty of the Naval War College, offered a campaign analysis of the entire war. Wallach's paper was introduced by the president of the Naval War College, Captain Henry C. Taylor. Unusual for a paper in Proceedings, it was indicative of official approval. Taylor emphasized for the readership the impact of the late Sino-Japanese on the officers at the college at the time and how serendipitous it proved to be:

The war between China and Japan began at a moment when the War College was engaged upon problems of naval campaigns. Some officers had already taken up, as an example of strategic principles, a situation based upon hostilities between [Japan and China], with Corea [sic] as a theater of operations. It was natural therefore that actual war coming at such a time should engross much of the attention of the officers in attendance at the session of 1894. At the close of the war I requested Captain Wallach, of the permanent staff of the college, to embody in a series of lectures the military operations of the Chinese and Japanese forces and his commentaries thereon. ${ }^{52}$

\footnotetext{
50 Marble, 521. Emphasis added.

51 See http://www.history.navy.mil/our-collections/photography/numerical-list-of-images/nhhcseries/nh-series/NH-54000/NH-54428.html (accessed 10 March 2016); see also Annual Report for the Secretary of the Navy 1906 (Washington, DC: US Government Printing Office, 1097), list of officers on special duty, Bureau of Equipment, 393.

${ }^{52}$ Captain H.C. Taylor, introduction to Captain Richard Wallach, US Marines "The War in the East," Proceedings, 21:4 (1895), 691. Emphasis added.
} 
Taylor also stressed the point paraphrased based on Marble's analysis, that there was much to be learned because "It is only after many facts of like qualities are gathered into a homogenous group that we begin to discover those threads of truth with which alone we may weave the fabric of a sound philosophy." 53 Taylor went on to become chief of staff for Admiral George Dewey at battle of Manila Bay. He was later responsible for the creation of the General Board of the Navy in 1900, serving as its de facto chief of staff, again under Dewey.

Wallach's subsequent operational analysis focused on both land and sea operations and reflected the marine's fascination with how effective the Japanese were at combined and amphibious operations in modern war. His writing was nearly as complimentary of the Japanese Army as Marble's was of the IJN. But he, possibly overstated the case of Japan's power and capability at the end of his article. He wrote, "Japan is at once the England and the Germany of the far East: she is invincible in her island home to any single nation that may come against her." 54 To Wallach's mind Japan had mastered land and sea power and her island geography gave her additional great advantages.

$* * *$

This limited body of evidence suggests some things that need more attention to understand a possible transformation in attitudes (however great or slight) in the US Navy officer corps vis-à-vis its counterparts in the Kaigun. There is evidence of disesteem and dismissal prior to the results of the war being generally known. But the shift in attitude and focus is especially made clear in Captain's Taylor remarks. It seems clear that any notion that Japan might not be up to Western standards, and able to challenge a Western nation (like Russia), had been disabused among significant populations in the US Navy officer corps. The officer corps appears to have gone from an attitude of grudging or even partial respect, due to ethnocentrism or racism, to one of clear respect and even awe. Some of its officers, like Taylor and Wainwright who later determined the course of the navy in the twentieth century, also saw Japan's triumph through a lens that offered the possibility for a more effective domestic US naval policy, whose neglect might spell the ruin of the nation.

How might this "trip back in time" inform our thinking about the present? "Recent or distant, history is all we have to go on, and we cannot escape it." ${ }^{55} \mathrm{We}$ often find that history offers no clear cut "lessons learned," rather it provides a basis to understand a very hazy present, it provides insight and, in some cases, wisdom for commanders and policy makers. Japan and the United States were far friendlier 120 years ago than the dominant narrative of US-Japanese relations of that period often portrays. Inside the US naval officer corps the evidence suggests a healthy

\footnotetext{
53 Ibid.

${ }_{54}$ Wallach, 692-736, 736. Emphasis added.

55 Rodger, "The Perils of History," 7.
} 
respect and even a desire to emulate the Japanese, both in terms of naval force structure and training excellence, but also a desire to emulate the wise policies and leadership of its (perceived) enlightened imperial government. The most important threat, as it turned out, in US perceptions of from 1890 to 1918 was Germany. War Plan Black (against Germany), which has not received as much attention as War Plan Orange (aimed at Japan), was the dominant concern of thinking and planning for most naval officers until Germany was finally humbled during the Great War. ${ }^{56}$

As tensions increased between Japan and the United States, especially at the end of the First World War and after, conflict was averted at the Washington Naval Conference in 1921-22. Japan's war hero and subsequent prime minister, Admiral Kato Tomosaburo, imagined a security policy based on no war with the United States and possibly an alliance. ${ }^{57}$ The Four Power Pact of Washington established that basis, a treaty upon which a security scheme of Japanese-American Pacific partnership could have been accomplished. ${ }^{58}$ But history is contingent and fickle. Kato died suddenly and his heirs - who included, surprisingly, Yamamoto Isoruko - continually lost ground to militarists as Japan's aggressive exploitations of a fractured China pushed the US and Japan further and further apart. ${ }^{59}$

Today, the situation looks similar, but with fundamental differences. China remains a challenge to US-Japanese relations, but Kato's dream of a US-Japanese partnership in the Pacific is one of the pillars for current US security policy in the region, if not the primary pillar of that policy. China seems to match better the challenge of Germany 120 years ago and, let us admit it, a resurgent Russia, both Pacific naval powers. Flipping the analogy on its head, China looks something like the emerging Japan of more than a century ago - although US policy until recently seemed to emphasize a willingness to cooperate, as the US and Japan were to do in 1900 during the Boxer Rebellion.

Let us not ignore that past but rather come to grips with it, and we might realize that US-Japanese friendship as like-minded progressive maritime powers is perhaps older than 1953, when the current relationship was formalized. ${ }^{60} \mathrm{We}$ might also extrapolate the challenge of China and realize that war is never inevitable or pre-determined if wise policy choices are made vis-à-vis our biggest trading partner in the Pacific.

\footnotetext{
56 Ronald W. Knisely, "The General Board of the United States Navy — its Influence on Naval Policy and National Policy," unpublished master's thesis, University of Delaware, June 1967, 89. 90.

57 Sadao Asada, "The Revolt Against the Washington Treaty: The Imperial Japanese navy and Naval Limitation, 1921-1927,", in The Naval War College Review (Summer 1993), 69-90.

58 Kuehn, Agents of Innovation, 147.

59 Sadao Asada, "The London Conference and the Tragedy of the Imperial Japanese Navy," in At the Crossroads Between Peace and War: The London Naval Conference of 1930, eds. John H. Maurer and Christopher M. Bell (Annapolis, MD: Naval Institute Press, 2014), 103, 119.

${ }^{60}$ Hara Kimie, "50 Years From San Francisco: Re-examining the Peace Treaty and Japan's Territorial Problems," in Pacific Affairs, 74:3 (Fall 2001), 361-382.
} 